\title{
Two distinct phases of apoptosis in mammary gland involution: proteinase-independent and -dependent pathways
}

Leif R. Lund ${ }^{1, *}$, John Rømer ${ }^{2}$, Nicole Thomasset ${ }^{3}$, Helene Solberg ${ }^{2}$, Charles Pyke ${ }^{2}$, Mina J. Bissell $^{3}$, Keld Dan $\varnothing^{2}$ and Zena Werb ${ }^{1, \dagger}$

${ }^{1}$ Laboratory of Radiobiology and Environmental Health, University of California, San Francisco, California 94143-0750, USA

${ }^{2}$ Finsen Laboratory, Rigshospitalet, Strandboulevarden 49, DK-2100 Copenhagen, Denmark

${ }^{3}$ Life Sciences Division, Lawrence Berkeley Laboratory, Berkeley, California 94720, USA

${ }^{*}$ Present address ${ }^{2}$

${ }^{\dagger}$ Author for correspondence:

e-mail: zena@radlab.ucsf.edu

LBNL/DOE funding \& contract number: DE-AC02-05CH11231

\section{DISCLAIMER}

This document was prepared as an account of work sponsored by the United States Government.

While this document is believed to contain correct information, neither the United States Government nor any agency thereof, nor The Regents of the University of California, nor any of their employees, makes any warranty, express or implied, or assumes any legal responsibility for the accuracy, completeness, or usefulness of any information, apparatus, product, or process disclosed, or represents that its use would not infringe privately owned rights. Reference herein to any specific commercial product, process, or service by its trade name, trademark, manufacturer, or otherwise, does not necessarily constitute or imply its endorsement, recommendation, or favoring by the United States Government or any agency thereof, or The Regents of the University of California. The views and opinions of authors expressed herein do not necessarily state or reflect those of the United States Government or any agency thereof or The Regents of the University of California. 


\section{Summary}

Postlactational involution of the mammary gland is characterized by two distinct physiological events: apoptosis of the secretory, epithelial cells undergoing programmed cell death, and proteolytic degradation of the mammary gland basement membrane. We examined the spatial and temporal patterns of apoptotic cells in relation to those of proteinases during involution of the BALB/c mouse mammary gland. Apoptosis was almost absent during lactation but became evident at day 2 of involution, when $\beta$-casein gene expression was still high. Apoptotic cells were then seen at least up to day 8 of involution, when $\beta$-casein gene expression was being extinguished. Expression of sulfated glycoprotein-2 (SGP-2), interleukin-1 $\beta$ converting enzyme (ICE) and tissue inhibitor of metalloproteinases-1 was upregulated at day 2, when apoptotic cells were seen initially. Expression of the matrix metalloproteinases gelatinase A and stromelysin-1 and the serine proteinase urokinase-type plasminogen activator, which was low during lactation, was strongly upregulated in parallel starting at day 4 after weaning, coinciding with start of the collapse of the lobulo-alveolar structures and the intensive tissue remodeling in involution. The major sites of mRNA synthesis for these proteinases were fibroblast-like cells in the periductal stroma and stromal cells surrounding the collapsed alveoli, suggesting that the degradative phase of involution is due to a specialized mesenchymal-epithelial interaction. To elucidate the functional role of these proteinases during involution, at the onset of weaning we treated mice systemically with the glucocorticoid hydrocortisone, which is known to inhibit mammary gland involution. Although the initial wave of apoptotic cells appeared in the lumina of the gland, the dramatic regression and tissue remodeling usually evident by day 5 was substantially inhibited by systemic treatment with hydrocortisone. mRNA and protein for gelatinase A, stromelysin-1 and uPA were weakly induced, if at all, in hydrocortisonetreated mice. Furthermore, mRNA for membrane-type matrix metalloproteinase decreased after hydrocortisone treatment and paralleled the almost complete inhibition of activation of latent gelatinase A. Concomitantly, the gland filled with an overabundance of milk. Our data support the hypothesis that there are at least two distinct phases of involution: an initial phase, characterized by induction of the apoptosisassociated genes SGP-2 and ICE and apoptosis of fully differentiated mammary epithelial cells without visible degradation of the extracellular matrix, and a second phase, characterized by extracellular matrix remodeling and altered mesenchymal-epithelial interactions, followed by apoptosis of cells that are losing differentiated functions.

\section{Key words}

apoptosis, matrix metalloproteinases, urokinase, extracellular matrix, involution, mammary gland 


\section{Introduction}

When sexually mature mice become pregnant, the mammary gland begins a fascinating cycle of lobulo-alveolar development and maturation that finally results in full functional differentiation and production of milk by the secretory epithelium during lactation. The extracellular matrix (ECM) maintains these structures in a functional conformation (Barcellos-Hoff et al., 1989; Streuli and Bissell, 1990; Talhouk et al., 1992; Walker et al. 1989). Equally remarkable are the morphological, ultrastructural and biochemical changes in the mammary gland after cessation of lactation. The involution that follows weaning results in the quenching of milk protein gene expression, collapse of the alveolar structures, removal of the secretory luminal epithelial cells and endothelial and myoepithelial cells by programmed cell death, phagocytosis by macrophages, proteolytic degradation of the basement membranes, and replacement of most of the epithelial cells by adipose tissue (Helminen and Eriksson, 1968; Lascelles and Lee, 1978; Marti et al., 1994; Strange et al., 1992; Talhouk et al., 1992; Walker et al., 1989; Williams, 1942). The structure of the involuting gland becomes almost identical to that of the resting virgin gland after 10-15 days, depending on the mouse strain studied (Lascelles and Lee, 1978).

Although the molecular mechanisms underlying the gain of function during mammary epithelium differentiation have been investigated intensively in recent years, the events during the loss of function have received much less scrutiny. During the maturation of the mammary gland, interactions between the mesenchyme and epithelium are important for normal development (Sakakura, 1991). The matrix metalloproteinases (MMPs) stromelysin-1, stromelysin-3 and gelatinase A and the serine proteinase urokinase-type plasminogen activator (uPA) increase during involution (Busso et al., 1989; Dickson and Warburton, 1992; Lefebvre et al., 1992; Li et al., 1994; Strange et al., 1992; Talhouk et al., 1992) and are probably responsible for the degradation of the ECM and basement membranes. The localization of stromelysin-3 in fibroblastic cells during involution (Lefebvre et al., 1992) suggests an active role for the mesenchyme, although no known function of stromelysin-3 has been described; similarly, stromelysin-1 and gelatinase A have been localized to the stromal or myoepithelial cells by immunohistochemical analysis (Dickson and Warburton, 1992; Talhouk et al., 1992; Li et al., 1994). In transgenic mice overexpressing stromelysin-1 during pregnancy or in mammary epithelial cells in culture, the degradation of ECM initiates apoptosis in part by inducing expression of interleukin-1 $\beta$ converting enzyme (ICE) (Boudreau et al., 1995). The increase in ICE and stromelysin-1 during involution is believed to be related to the apoptotic process. The aim of the present study was to explore the relationship of apoptosis of mammary epithelium to tissue remodeling during involution and to investigate mesenchymal-epithelial interactions during involution. We have examined the temporal and spatial expression and function of stromelysin-1, gelatinase A and uPA in relation to the other physiological events that take place during involution of the mammary gland.

\section{Materials and Methods}

\section{Materials}

T7, T3 and SP6 RNA polymerases, RNase inhibitor, restriction endonucleases, a random DNA labeling kit and monoclonal antibodies specific for macrophages (Mac-1 and Mac-2) were 
obtained from Boehringer Mannheim, Germany. A monoclonal antibody directed against mouse smooth muscle $\alpha$-actin (clone no. 1A4), amiloride, $\beta$-estradiol 17-acetate, progesterone, testosterone acetate and hydrocortisone 21-acetate were obtained from Sigma Chemical Company (St Louis, MO). The Apoptag kit for detection of apoptotic cells was obtained from Oncor Inc. (Gaithersburg, MD) and Superfrost ${ }^{+}$slides were obtained from Fisher Scientific (Pittsburgh, PA). All other materials used were described earlier (Rømer et al., 1991; Kristensen et al., 1991a,b; Pyke et al. 1994; Talhouk et al., 1992; Sympson et al., 1994).

\section{Animal and tissue treatment procedures}

Tissue from mammary glands was isolated from BALB/c mice in their first pregnancy. The mice were obtained either from the Fibiger Institute (Copenhagen, Denmark) or from Charles River (Wilmington, MA). The tissue was collected from mice at various stages of lactation or during involution of the mammary gland after cessation of lactation. The number of pups was adjusted to 7 for each mouse; they were allowed to lactate for 7 days in order to reach a state of full lactation, before the offspring were removed. The intervals for involution are indicated for each experiment. Tissue samples from at least 3 mice were collected and analyzed separately for each stage in the experiment. The mice were anesthetized by intraperitoneal injection of avertin and perfused intracardially with $20 \mathrm{ml}$ ice-cold phosphatebuffered saline (PBS). The inguinal and abdominal mammary glands were removed for RNA isolation or protein extraction as described below. The mice used for in situ hybridization and immunohistochemistry were treated similarly, except that perfusion with cold PBS was followed by intracardial perfusion-fixation with 4\% $(\mathrm{w} / \mathrm{v})$ paraformaldehyde in PBS. The mammary glands were removed and postfixed for 16 hours in 4\% paraformaldehyde in PBS. The tissue was then rinsed in PBS, dehydrated and embedded in paraffin. For all the morphological analyses, only the left and right inguinal (number 4) mammary glands were used. For histological analyses, sections from all tissue samples were routinely stained with hematoxylin and eosin, Gomori's one-step trichrome stain or toluidine blue. The percentage of collapsed alveoli versus intact secretory alveoli at each time point postweaning was determined by analyzing 200 alveoli and assessing their physiological state in sections from two different animals. In some cases, either at the start of involution or at various times after weaning, the mice were treated daily with subcutaneous injection of $0.5 \mathrm{mg}$ of hydrocortisone 21-acetate in PBS per g body weight. All experiments were performed under protocols approved by the Danish Animal Research Committee, the Animal Welfare and Research Committee (Lawrence Berkeley Laboratory) or the Committee on Animal Research (University of California, San Francisco).

\section{Preparation of RNA probes}

The following fragments of mouse uPA (Belin et al., 1985), mouse gelatinase A (Reponen et al., 1992), mouse gelatinase B (Reponen et al., 1994) and mouse stromelysin-1 (Hammani et al., 1992) were subcloned: for UPA, pMUPA07 fragment (608-1642) in pGEM5z, or pMUPA09 fragment (37-428) in pBluescript KS(+); for gelatinase A, (604-1165) fragment in pSP64 and pSP65 or the HaeIII fragment (1924-2259) in pGEM-3; for gelatinase B, (805-1099) fragment in pSP64 and pSP65; for stromelysin-1, pmTRM11 fragment (3115-4051) and pmTRM12 fragment (2205-2918) in pBluescript KS(+). Pure plasmid preparations were made by banding through a $\mathrm{CsCl}$ gradient and, before transcription, the plasmids were linearized by using the following 
restriction endonucleases: pMUPA07, PstI or EcoRI; pMUPA09, BamHI; pSP64, EcoRI; pSP65, HindIII; pmTRM11, SacI or KpnI; pmTRM12, SacI or XhoI. The in vitro RNA transcriptions were performed as described previously (Rømer et al., 1991) and the labeled probes were stored at $-20^{\circ} \mathrm{C}$ until use.

\section{In situ hybridization analysis of mRNA}

In situ hybridization was performed essentially as described by Kristensen et al. (1991a). Briefly, $5 \mu \mathrm{m}$ paraffin sections on Superfrost ${ }^{+}$slides were treated as described by Pyke et al. (1994). After hybridization overnight at $47^{\circ} \mathrm{C}$ with radiolabeled RNA probes, the sections were washed, treated with RNase A (20 $\mu \mathrm{g} / \mathrm{ml})$ and RNase T1 (20 U/ml), dehydrated and air-dried. Autoradiographic emulsion was applied, and sections were developed after 10 days of exposure, lightly counterstained with either hematoxylin and eosin or Gomori's trichrome stain and mounted with Permount. The presence of apoptotic cells was detected by means of the Apoptag kit (Oncor).

\section{Immunohistochemical analysis}

The sections were deparaffinized in xylene, rehydrated with ethanol, rinsed in water and incubated for 10 minutes at $37^{\circ} \mathrm{C}$ with $0.1 \%(\mathrm{w} / \mathrm{v})$ trypsin in $0.05 \mathrm{M} \mathrm{Tris} / \mathrm{HCl}$ and $0.1 \%(\mathrm{w} / \mathrm{v})$ $\mathrm{CaCl} 2, \mathrm{pH}$ 7.4. Macrophages were stained with antibodies against Mac-1 and Mac-2 antigens, as described previously (Feiken et al., 1995), by using the alkaline phosphatase anti-alkaline phosphatase method (Cordell et al., 1984). Smooth muscle $\alpha$-actin was stained with a biotinconjugated monoclonal primary antibody, followed by streptavidin-AP complex (D396; Dako, Copenhagen, Denmark). For all the immunohisto-chemical analyses, control experiments were performed in which primary or secondary antibodies were omitted.

\section{RNA isolation and analysis}

Total RNA was isolated from the inguinal and abdominal mammary glands from at least three mice at each stage of involution or treatment, by the acid guanidine-thiocyanate-phenolchloroform method (Chomczynski and Sacchi, 1987). The concentration of total RNA in the samples was determined spectrophotometrically, and either RNA was used directly for RNA blotting analysis (Talhouk et al., 1992) or poly(A)+ RNA was isolated (Rømer et al., 1991) and used for reverse transcription-polymerase chain reaction (RT-PCR) analysis (Ploug et al., 1992). Total RNA (20 $\mu \mathrm{g})$ was denatured and separated in 1.5\% agarose/formaldehyde gels. The RNA blots were hybridized with the antisense RNA probes used for the in situ hybridizations for gelatinase $\mathrm{A}$, stromelysin-1 or uPA, or with the following random-primed labeled cDNA probes: mouse ICE (Boudreau et al. 1995), mouse stromelysin-2 (Gack et al., 1994), $\beta$-casein (pBCL1), mouse tissue inhibitor of metalloproteinases (TIMP)-1 (Gewert et al., 1987) and TIMP-2 (Alexander and Werb, 1992), mouse sulfated glycoprotein-2 (SGP-2) (Strange et al., 1992), mouse plasminogen activator inhibitor (PAI)-1 (Prendergast and Cole, 1989) and mouse PAI-2 (Belin et al., 1989), or a cDNA for human membrane-type (MT)-MMP (Sato et al., 1994). For the latter, less stringent conditions were used in the washing procedure: 1 hour with $2 \times$ SSC ( $1 \times$ SSC $=0.15 \mathrm{M}$ sodium chloride, $0.015 \mathrm{M}$ sodium citrate), $0.1 \%$ sodium dodecyl sulfate (SDS) at $42^{\circ} \mathrm{C}, 1$ hour with $2 \times \mathrm{SSC}, 0.1 \%$ SDS at $68^{\circ} \mathrm{C}$, and finally for 1 hour with $0.5 \times \mathrm{SSC}, 0.1 \%$ 
SDS at $68^{\circ} \mathrm{C}$. The blots were exposed to Kodak X-AR 5 film for various times, as indicated in the figure legends. As a control for equal loading, the blots were stripped and rehybridized with a cDNA probe for 28S RNA. For quantification of the signals, the RNA blots were analyzed in a Molecular Dynamics PhosphorImager SF. Detection of uPA receptor (uPAR), PAI1 and PAI-2 mRNA by means of RT-PCR generally followed the scheme described previously (Ploug et al., 1992).

\section{Mammary gland protein extract}

The extracts used for gelatinolytic assays were prepared as described previously (Talhouk et al., 1991) from the inguinal and abdominal mammary glands from at least three mice for each stage. The extracts for uPA fibrin zymography and enzyme-linked immunosorbent assay (ELISA) were isolated as described (Andreasen et al., 1990a). The protein concentrations of the extracts were determined by the Folin-Ciocalteu phenol reagent, with bovine serum albumin as a standard.

\section{Zymography}

The gelatinolytic assays were carried out as described in detail previously (Talhouk et al., 1991), and plasminogen activator activity was detected in casein gels with plasminogen added (Talhouk et al., 1991). As control for specificity, plasminogen was omitted from the substrate gel, and mouse bladder urine was used as a positive control for uPA activity. Alternatively, plasminogen activator activity in the SDSpolyacrylamide gels was detected by fibrin zymography as described by Andreasen et al. (1990a).

\section{Enzyme-linked immunosorbent assay for uPA}

A Nunc 96-well immunoplate (Maxisorp) was coated overnight at $4^{\circ} \mathrm{C}$ with $2 \mu \mathrm{g} / \mathrm{ml}$ rabbit antimouse uPA IgG in $0.1 \mathrm{M}$ Na2CO3, $\mathrm{pH}$ 9.8. Remaining protein binding sites were saturated with $1 \%(\mathrm{w} / \mathrm{v})$ bovine serum albumin in PBS for 3 minutes at $37^{\circ} \mathrm{C}$. Extract samples with unknown concentrations of mouse uPA were analyzed either alone or together with a mouse uPA standard (concentration determined by amino acid analysis) diluted in $1 \%(\mathrm{w} / \mathrm{v})$ bovine serum albumin in PBS, $0.1 \%(\mathrm{v} / \mathrm{v})$ Tween 20 (buffer A) and incubated for 1 hour at ambient temperature with shaking. The bound uPA was measured by adding biotinylated rabbit anti-mouse uPA IgG (2 $\mu \mathrm{g} / \mathrm{ml}$ in buffer A) for 1 hour at ambient temperature with shaking, followed by peroxidaseconjugated avidin (P347; Dako) diluted in buffer A and incubated for 1 hour at ambient temperature with shaking. The ELISA was developed as described previously (Andreasen et al., 1990a).

\section{Results}

\section{Relationship of morphological changes to expression of mRNA and protein for ECM remodeling proteinases in the mammary gland during involution}

At the time of weaning, the lactating mammary gland of BALB/c mice consisted mainly of clusters of alveoli lined by a cuboidal epithelium secreting milk proteins, carbohydrates and lipids into the lumina of the alveoli (Fig. 1A,B). There was a well-branched ductal system, with 
the larger ducts surrounded by a basement membrane and thicker layers of connective tissues. The lobules were enclosed by fibrous septae. In addition, there was an extensive vascular and lymphatic network. The well-organized, secretory lobuloalveolar structures characteristic of lactating animals remained intact for the first 3 days after weaning (Fig. 1C-F). Up to day 3 postweaning, more than $95 \%$ of all alveoli remained intact, followed by collapse of $60 \%$ of the alveoli at day $4,70 \%$ at day 5, $85 \%$ at day 7 , and $\geq 95 \%$ at day 10 . By trichrome staining, we found connective tissue collagens around major ducts and vessels, whereas only very faint staining or none was observed around the intact lobules and the interstitial septae (Fig. 1D). Severe distension was observed in all alveoli at days 1 and 2 after weaning, owing to the continuous synthesis and secretion of milk for up to 2 days after weaning; partial disruption of some of the alveolar basal membranes and flow of liquid into the interstitium was seen after 2 or 3 days of involution. Infiltration of adipocytes began at day 2 after weaning.

The number of epithelial cells undergoing apoptosis and shedding into the alveolar lumina increased dramatically between 2 and 3 days after weaning, as detected both by conventional morphological criteria (Fig. 1C-F) and by specific staining for apoptopic cells (Fig. 1K,L). This occurred without visible changes in the relationship between mesenchymal and epithelial compartments. There followed a distinct second phase of involution involving very intensive tissue remodeling that started at 4 days after weaning, when the lobuloalveolar structure collapsed (Fig. 1G-J). At day 4, the parenchyma consisted mainly of ducts, vessels and clusters of epithelial cords, some with small lumina, all surrounded by condensed connective tissue and increasing numbers of adipocytes (Fig. 1H). Further degradation of the secretory structures and a dramatic increase in the number of adipocytes continued up to day 8 (Fig. 1I,J). A few, isolated secretory alveoli and ducts containing secretory material surrounded by adipocytes and interspersed by thickened stromal elements remained present for up to 16 days after weaning. The mammary gland was fully regressed after 21 days and reorganized with ducts, ready for another cycle of pregnancy and lactation (data not shown).

Molecular analysis of gene expression also revealed two distinct phases of involution. Differentiated function, as measured by $\beta$-casein mRNA expression, decreased from the very high levels during lactation to one fourth by day 3 after weaning, a level similar to that at the end of pregnancy, and then to even lower levels over the next 2 days (Fig. 2C,D). Whereas ICE, SGP-2 and TIMP-1 mRNA increased during the first 2 days after lactation and then decreased (Fig. 2A,B), stromelysin-1 and uPA mRNAs were low in lactating mammary gland and during the first 3 days after weaning, then increased 30-fold on day 4, followed by a gradual decrease up to day 10 (Fig. 2C,D). Gelatinase A mRNA was expressed at much lower levels, although with an induction pattern similar to that of stromelysin-1 and uPA (Fig. 2C,D). In contrast, the single $3.5 \mathrm{~kb}$ MT-MMP mRNA band, which we detected in mammary gland after 7 days of lactation and throughout involution, remained unchanged (Fig. 2C). TIMP-2 mRNA was not regulated and was present at low levels throughout the 16 days after weaning (Fig. 2A). No signal for stromelysin-2 was detected (data not shown). As measured by RT-PCR analysis on poly(A)+ RNA samples, uPAR mRNA increased after the start of involution, whereas little PAI-1 and PAI-2 mRNA was detected during lactation and involution (data not shown). These data suggest that the initial involution events at 1 to 3 days after weaning have a pattern of gene expression that is distinct from that of the major remodeling phase from days 4-10. 
Protein extracts prepared from the same mice used for RNA isolation were analyzed by zymography. Although no active gelatinase A was present in extracts isolated from lactating mice, active gelatinase A began to be observed at day 2 of involution (data not shown). The amount of both latent and active forms of gelatinase A increased between days 2 and 3 after weaning and increased further with involution time. The highest activity was present at day 10 after weaning, consistent with the RNA data. A sandwich ELISA was used to obtain a quantitative measurement of the amount of uPA in the mammary gland. As shown in Fig. 3, the concentrations of uPA, normalized against the total protein concentration in the extracts, increased during the first 7 days after weaning, then declined. Analysis of the same extracts by fibrin overlay zymography showed a similar expression pattern for uPA, with the highest activity in extracts from day 7 involuting mammary gland (Fig. 3, inset). A single band of uPA activity, with molecular mobility corresponding to $48 \times 10^{3} \mathrm{Mr}$, and the $68 \times 10^{3} \mathrm{Mr}$ band corresponding to tissue-type plasminogen activator (tPA) were detected (Talhouk et al., 1992).

\section{Expression of stromelysin-1, gelatinase A and uPA mRNA in the mesenchymal compartment during lactation and involution}

Because the initial apoptotic events and the rapid remodeling phases of involution appeared to be distinct, we next used in situ hybridization to determine which cell types expressed stromelysin1, gelatinase A and uPA mRNA. First, we examined the distribution of proteinase mRNA during lactation. Using serial sections of 7-day lactating glands, we detected gelatinase A and stromelysin-1 mRNA in the same fibroblast-like periductal stromal cells that surrounded most but not all intact ducts (Fig. 4A,B), as well as around some blood vessels (data not shown). Higher magnification showed no signal was detected in epithelial or myoepithelial cells (Fig. 5A-D), and no specific signal above background was seen when sense probes for stromelysin-1 (Fig. 5E), gelatinase A or uPA (data not shown) were used. Notably, the myoepithelial cells and most stromal cells surrounding the secretory alveoli were negative for stromelysin-1 and gelatinase A mRNA. The localization of stromelysin-1 mRNA mainly to cells in the stroma was further confirmed by following in situ hybridization with trichrome staining, which showed that the positive cells were enmeshed in connective tissue (see Fig. 7E,F). uPA mRNA was present in very few scattered fibroblast-like cells, not necessarily the same cells that were positive for gelatinase A and stromelysin-1 (Fig. 5B). The few uPA-positive fibroblast-like cells were found equally in the periductal and alveolar stroma. It should be noted that, in areas where the alveoli were distended by secretory material, the interalveolar space was very compressed; in such areas it was difficult to distinguish between a fibroblast-like stromal cell and myoepithelial cell as the source of the signal.

The number and intensity of cells positive for gelatinase A, stromelysin-1 and uPA mRNA increased dramatically throughout involution of the mammary gland, particularly after day 4, although with a heterogeneous and focal distribution mainly in fibroblast-like stromal cells (Fig. 6). Stromelysin-1 was detected mainly in the stromal compartment of clusters of degenerating alveoli and in the connective tissue around some of the ducts, as shown by in situ hybridization followed by positive trichrome staining (Fig. 7D). None of the cells (apoptotic cells and macrophages) present in the alveolar and ductal lumina were positive for either stromelysin-1 or gelatinase A, although some cells in the lumina were positive for uPA mRNA at day 5 and later stages of involution (Figs 7,8A,B). From serial sections, it was evident that the same clusters of 
stromal cells were positive for stromelysin-1, gelatinase A and uPA mRNA on day 7 of involution (Fig. 7A-C), but it was not clear if the same cells were positive for the three proteinases. We were unable to detect uPAR, PAI-1, PAI-2 and gelatinase B mRNA by in situ hybridization in either lactating or involuting glands (data not shown).

\section{Cellular sources of proteinases in the mammary gland during lactation and involution}

To determine the specific cells that expressed mRNA as seen by in situ hybridization, we identified specific cell types in the mammary gland. Few macrophages staining for Mac-2, a macrophage-specific antigen, were seen during lactation and during the first phase of involution, but their number increased dramatically from day 3 of involution. At day 6, the macrophages were localized mainly to the connective tissue around and within collapsed alveoli (Fig. 8C) and in the lumina of the larger ducts (Fig. 7C) and, by day 10 after weaning, the number of macrophages had increased further (data not shown). However, in adjacent serial sections, it was clear that the macrophages were not a major source of mRNA for uPA (Fig. 8A,B), stromelysin1 or gelatinase A (data not shown).

The myoepithelial cells, identified by immunohistochemical staining for smooth muscle $\alpha$-actin (Gugliotta et al., 1988), were seen in basket-like formations around collapsed alveoli (Fig. $8 \mathrm{E}, \mathrm{G}, \mathrm{I})$. Some single cells were also strongly positive for smooth muscle $\alpha$-actin. Because most of the cells positive for smooth muscle $\alpha$-actin were negative for uPA mRNA and most of the cells positive for uPA mRNA were negative for smooth muscle $\alpha$-actin, we concluded that myoepithelial cells cannot be the major source of uPA mRNA (Fig. 8D,E). Similarly, most of the cells positive for smooth muscle $\alpha$-actin were also negative for both gelatinase $A$ and stromelysin-1 (Fig. 8F,G and H,I, respectively).

\section{Regulation of involution by systemic treatment with Glucocorticoids}

To analyze the contribution of these proteinases to involution, we treated mice with glucocorticoids, which have been shown to downregulate MMPs and uPA in other systems (for reviews, see Andreasen et al., 1990b; Mignatti and Rifkin, 1993). Systemic daily treatment of the postlactating mice with hydrocortisone, starting on day 1 of weaning, delayed the massive remodeling, apoptosis and regression of the gland at least up to day 10 in a dose-dependent manner (Fig. 9B). Macroscopically, the glands were white and enlarged, owing to the accumulation of milk proteins in the gland. In histological sections, day 5 involuting glands from hydrocortisone-treated mice were clearly distinguishable from normal day 5 involuting gland and resembled normal day 3 involuting gland (see Fig. 1F). There were many apoptotic cells in the lumina of the alveoli and ducts, but the lobular-alveolar structures were still intact and there were few infiltrating and maturating adipocytes. The start of hydrocortisone treatment could be delayed up to 3 days after weaning and still delay the regression of the gland considerably, as judged by morphological and biochemical criteria (data not shown). The hydrocortisone-treated mice, as compared with the saline-treated normal involuting mice, showed little or no induction of uPA, gelatinase A and stromelysin- 1 mRNAs at day 5 after weaning. Moreover, in the hydrocortisone-treated gland, $\beta$-casein decreased only to approximately $35 \%$ of its lactating level, similar to that of a normal day 2 involuting gland, whereas in the saline-treated involuting mice it decreased to 5\% (Figs 2C,D, 9D). Interestingly, the signal for MT-MMP mRNA was 
totally abolished by the hydrocortisone treatment (Fig. 9D). This contrasts with untreated and saline-treated mice, which expressed this gene during lactation, when no tissue remodeling takes place (Fig. 2C). By zymography, no active gelatinase A was detected in extracts prepared from the hydrocortisone-treated mice, whereas latent gelatinase A was still detectable, but at lower levels than in the saline-treated controls. Identical results were obtained in all mice tested $(n=5)$. Similarly, uPA and, to a lesser extent, tPA activity was reduced (Fig. 9C). Thus, hydrocortisone maintained an early involuting phenotype while preventing the main remodeling phase. Hydrocortisone had no visible effect on the morphology of the mammary gland or gelatinolytic activity of age-adjusted virgin mice for up to 5 days (data not shown). No effect was detected after treatment of involuting mice with $\beta$-estradiol, progesterone or testosterone for 5 days (data not shown).

\section{Discussion}

\section{Involution of mammary gland is characterized by two distinct phases}

By a combination of biochemical and histological analysis and pharmacological interventions, we have demonstrated that the postlactational involution of the mammary gland can be divided into two distinct phases, each characterized by specific gene expression: an early phase characterized by engorgement of the gland with milk and initial apoptosis of epithelial cells, which accumulate in the lumina, and a second phase characterized by biosynthesis of proteinases and intensive tissue remodeling. During the first phase, mammary gland-specific differentiated functions, characterized by $\beta$-casein mRNA expression, remained relatively high, declining to about one fourth of the lactating level at day 3 after weaning, comparable to the levels in late pregnancy. At this time in the involution process, very low levels of MMPs, uPA and tPA were present in the gland, whereas TIMP-1 was upregulated, shifting the proteolytic balance in favor of inhibition. During this initial phase of involution there was a strong, transient induction of SGP-2 and ICE mRNA, two genes participating in the apoptotic process (Fig. 2A,B); a third gene, $p 53$, shows a more prolonged induction (Boudreau et al., 1995; Guenette et al., 1994; Strange et al., 1992). The second phase began at day 4 of involution in BALB/c mice and was characterized by upregulation of mRNA and activity for proteolytic enzymes, including gelatinase A, stromelysin-1 and uPA, and downregulation of the inhibitor TIMP-1, resulting in active tissue remodeling, including destruction of basement membranes and alveolar structures and irreversible loss of the differentiated function of the mammary gland (Martinez-Hernandez et al., 1976, Warburton et al., 1982).

\section{Regulation of proteolytic activity during involution}

Both MMPs and uPA and their specific inhibitors have been implicated in a number of degradative processes, such as wound healing, ovulation, trophoblast invasion, involution of the prostate and cancer invasion (for reviews see Alexander and Werb, 1991; Andreasen et al., 1990b; Birkedal-Hansen et al., 1993; Danø et al., 1985, 1994; Matrisian, 1990; Vassalli et al., 1991; Woessner, 1991). The results reported here also strongly support a physiological role of the proteinases in active tissue remodeling. The overall proteolytic activity is regulated at different, independent levels. Both MMPs and uPA are secreted as latent proenzymes with very little or no enzymatic activity. Activation of the proenzymes is an important regulatory step in 
the control of proteolytic activity. Although the mechanism by which the latent proenzymes are activated in vivo is unknown, in vitro experiments have indicated that plasmin and other proteolytic enzymes are able to activate prourokinase and procollagenase (Petersen et al., 1988; Werb et al., 1977). Recently, MT-MMP has been shown to activate progelatinase A in vitro (Sato et al., 1994). Furthermore, the enzymatic activity of MMPs and uPA is controlled by specific inhibitors. Members of the MMP family are inhibited by TIMP-1, TIMP-2 or TIMP-3, whereas uPA is inhibited by PAI-1 or PAI-2. Expression of gelatinase A, stromelysin-1 and uPA and of their specific inhibitors is regulated by a number of growth factors and cytokines in vitro (for reviews, see Andreasen et al., 1990b; Laiho and Keski-Oja, 1989; Mignatti and Rifkin, 1993), but which factors are responsible for the concerted increase in mRNA and protein levels during involution of the mammary gland are unknown. It has been shown that protein kinase A and c-Fos/c-JunD are induced during involution of the mammary gland (Marti et al., 1994), suggesting that these transduction signal pathways are involved in the regulation of specific gene expression. During development of the mammary gland, a number of growth factors are implicated in the mesenchymal-epithelial interactions, including members of the transforming growth factor- $\beta$ and fibroblast growth factor families (Coleman-Krnacik and Rosen, 1994; Jhappan et al., 1993; Maier et al., 1991; Robinson et al., 1991; for a review see Topper and Freeman, 1980). Similar studies are required to elucidate the molecular mechanisms involved during involution of the mammary gland.

Interestingly, we were able to detect uPA only in its high molecular weight form during mammary gland involution. Most of the uPA detected in the involuting ventral prostate occurs in the low molecular weight form (Andreasen et al., 1990a), which, although enzymatically active, cannot bind to uPAR (Stoppelli et al., 1985). A recent study has shown that matrilysin, a metalloproteinase of the stromelysin subclass, which is able to cleave uPA in vitro into low molecular weight uPA and its amino terminal fragment (Marcotte et al., 1992), is also induced during involution of the ventral prostate after hormonal ablation (Bowden et al., 1995). The level of uPA in the involuting mammary gland in the present study was approximately one tenth of that in the involuting prostate (Andreasen et al., 1990a). These data suggest that uPA may have different physiological roles in these two involuting organ systems.

\section{Mesenchymal-epithelial interaction in involution}

We have identified the cells responsible for the synthesis of gelatinase A, stromelysin-1 and uPA. In contrast to earlier studies (Busso et al., 1989; Dickson and Warburton, 1992; Li et al., 1994; Ossowski et al., 1979; Strange et al., 1992), we found that, for gelatinase A, stromelysin-1 and uPA, both mRNA and protein were expressed during lactation, although at a low level, as detected by zymograms and RNA blots. By in situ hybridization, we found that the mRNA for gelatinase A, stromelysin-1 and uPA in lactating mammary glands was synthesized by some but not all fibroblastlike periductal stromal cells. Similarly, during involution, the signals for the three proteinases were found in both periductal and perialveolar fibroblastlike stromal cells, although with a very focal and heterogeneous distribution. The data described here are in apparent disagreement with findings described by Dickson and Warburton (1992) and Li et al. (1994). By immunohistochemical analysis, these investigators found that myoepithelial cells were the source of positive immunoreactivity for both stromelysin- 1 and gelatinase A during 
involution of the rat and mouse mammary gland, respectively. We also observed that immunoreactive gelatinase A and stromelysin-1 are enriched in myoepithelial cells (data not shown). Similarly, uPA immunoreactivity was localized to the epithelial cells (Larsson et al., 1984). A possible explanation for the apparent discrepancy between the immunocytochemistry and in situ hybridization could be that, although fibroblasts synthesize and secrete the proteinases, after secretion these enzymes are bound to other cell types or to ECM components in the mammary gland. It is interesting to note that similar discrepancies exist for mRNA and protein localization for MMPs in tumor tissue (Garbisa et al., 1990; Pyke et al., 1993; StetlerStevenson et al., 1993). Our data directly confirm the indirect observation by Ossowski et al. (1979) that macrophages cannot be the major source of uPA production. In agreement with earlier observations (Mayberry, 1964), we also demonstrated that the influx of macrophages into the mammary gland is a late event during involution. Furthermore, we have shown that macrophages are not the source of either stromelysin-1 or gelatinase A, supporting the role of macrophages as scavengers.

A similar, but not identical, temporal and spatial expression pattern has been described for stromelysin-3 during development, differentiation and involution of the mammary gland. Although no mRNA for stromelysin-3 was detected during development and pregnancy or lactation, during involution it was detected at day 3, with maximal expression by day 6 in fibroblasts around the disorganized clusters of epithelial cells (Lefebvre et al., 1992). As we observed for stromelysin-1 and gelatinase A, epithelial cells were negative for stromelysin-3. Taken together, these data suggest a major contribution of both the epithelium and the neighboring fibroblasts in the proteolytic degradation of the ECM during involution. Thus, like development (Sympson et al., 1994) and cancer invasion (Danø et al., 1994), involution of epithelia requires the collaboration of mesenchymal and epithelial cells. In the cell culture model system for apoptosis and involution that we have developed (Boudreau et al. 1995), the CID-9 mammary cell strain contains populations of both epithelial and mesenchymal-like cells. It will be interesting to see if such an interaction can be reconstituted in culture models of involution, using defined populations of mammary and epithelial cells and fibroblastic cells such as those described by Desprez et al. (1993).

\section{Regulatory mechanisms involved in glucocorticoid inhibition of tissue remodeling during involution}

We used hydrocortisone treatment to separate the two phases of involution. Hydrocortisone had no effect on the initial apoptosis, even though it decreased the already low basal levels of proteinases. However, it completely blocked the second, remodeling phase, even when added as late as day 3 of involution. Two observations support the hypothesis that hydrocortisone has a specific action in inhibiting the proteolytic phase, rather than just maintaining the lactational state: (1) the fact that MT-MMP mRNA was abolished by hydrocortisone, and (2) the observation that the early involutional phase, characterized by the release of apoptotic cells into the alveolar and ductal lumina, was not completely inhibited by hydrocortisone. Hydrocortisone treatment had multiple physiological effects, although they all worked in a concerted manner: the treatment downregulated gelatinase A, stromelysin-1 and uPA mRNAs and protein. These data suggest that gelatinase A, stromelysin-1 and uPA gene expression is under hormonal control in vivo. 
A new observation with important implications was the almost complete inhibition of activation of latent gelatinase A by hydrocortisone treatment. With the downregulation of all the MMPs, the relative tissue concentrations of TIMP- 1 and- 2 would increase, possibly affecting activation. In this context, it is an important finding that MT-MMP, a potential activator of progelatinase A (Sato et al., 1994; Cao et al., 1995), is also downregulated by hydrocortisone treatment. In a recent study MT-MMP and gelatinase A, but not stromelysin-1 and interstitial collagenase, were shown to be co-expressed by stromal cells in human colon, breast and head and neck cancer (Okada et al., 1995). These data suggest that this newly discovered member of the MMP family could play a significant role in the regulation of overall proteolytic activity. Future studies are required to determine the cells responsible for the synthesis of MT-MMP in the mammary gland and the biochemical effects of this potential activator of progelatinase A in vivo. Glucocorticoid treatment has earlier been shown to inhibit the involution of the ventral prostate gland after castration and to affect apoptosis-related gene expression (Rennie et al., 1989; Freeman et al., 1990). Glucocorticoid treatment reduces the plasminogen activity in the ventral prostate by decreasing the level of uPA mRNA and protein, whereas no effect on PAI-1 protein level can be detected (Freeman et al., 1990). Similar analyses are required for a detailed molecular understanding of the inhibitory effect of glucocorticoids on the involution of the mammary gland.

\section{Acknowledgments}

We thank Dr K. Tryggvason and Dr Y. Eeckhout for the gift of plasmids for mouse gelatinase A and B and stromelysin-1, respectively, Dr D. Belin for the mouse uPA and PAI-2 cDNA, Dr H. Sato for the human MT-MMP cDNA and Dr R. Strange for the SGP-2 cDNA. The excellent technical assistance of Ole Behrendtsen, Dorte Holm, Kirsten Lund Jakobsen, Jette Mandelbaum and Anne Margrethe Poulsen is gratefully acknowledged. We thank Mary McKenney for editing the manuscript. This work was supported by the Danish Cancer Society, the Danish Biotechnology Program, Fru Astrid Thaysens Legat for Loege-videnskabelig Grundforskning, the Danish Medical Research Council, the National Cancer Institute (grant CA 57621), the Women's Health Initiative, Office of the Director NIH (CA 5762151), the US Department of Energy, Office of Health and Environmental Research (contracts DE-AC03-76-SF01012 and DE-AC03-76-SF00098), Institut Nationale de la Santé et de la Recherche Medicale (INSERM) and a fellowship from NATO.

\section{References}

Alexander, C. M. and Werb, Z. (1991). Extracellular matrix degradation. In Cell Biology of Extracellular Matrix, 2nd ed. (ed. E. D. Hay), pp. 255-302. New York: Plenum.

Alexander, C. M. and Werb, Z. (1992). Targeted disruption of the tissue inhibitor of metalloproteinases gene increases the invasive behavior of primitive mesenchymal cells derived from embryonic stem cells in vitro. J. Cell Biol. 118, 727-739.

Andreasen, P. A., Kristensen, P., Lund, L. R. and Danø, K. (1990a). Urokinase-type plasminogen activator is increased in the involuting ventral prostate of castrated rats. Endocrinology 126, 2567-2576.

Andreasen, P. A., Georg, B., Lund, L. R., Riccio, A. and Stacey, S. N. (1990b). Plasminogen activator inhibitors: Hormonally regulated serpins. Mol. Cell. Endocrinol. 68, 1-19. 
Barcellos-Hoff, M. H., Aggeler, J., Ram, T. G. and Bissell, M. J. (1989). Functional differentiation and alveolar morphogenesis of primary mammary cultures on reconstituted basement membrane. Development 105, 223-235.

Belin, D., Vassalli, J.-D., Combèpine, C., Godeau, F., Nagamine, Y., Reich, E., Kocher, H. P. and Duvoisin, R. M. (1985). Cloning, nucleotide sequencing and expression of cDNAs encoding mouse urokinase-type plasminogen activator. Eur. J. Biochem. 148, 225-232.

Belin, D., Wohlwend, A., Schleuning, W.-D., Kruithof, E. K. O. and Vassalli, J.-D. (1989). Facultative polypeptide translocation allows a single mRNA to encode the secreted and cytosolic forms of plasminogen activators inhibitor 2. EMBO J. 8, 3287-3294.

Birkedal-Hansen, H., Moore, W. G. I., Bodden, M. K., Windsor, L. J., Birkedal-Hansen, B., DeCarlo, A. and Engler, J. A. (1993). Matrix metalloproteinases: a review. Crit. Rev. Oral Biol. Med. 4, 197-250.

Boudreau, N., Sympson, C. J., Werb Z. and Bissell, M. J. (1995). Suppression of ICE and apoptosis in mammary epithelial cells by extracellular matrix. Science 267, 891-893.

Bowden, G. T., Knox, J. D., Powell, W. C., von Bredow, D. C., Sundareshan, P., Klein, R. D., Boyd, J. L., Cress, A. E. and Nagle, R. B. (1995). The role of matrilysin in human prostate tumor cell invasion. J. Cell. Biochem. Suppl. 19B, 3.

Busso, N., Huarte, J., Vassalli, J.-D., Sappino, A.-P. and Belin, D. (1989). Plasminogen activators in the mouse mammary gland. Decreased expression during lactation. J. Biol. Chem. 264, 7455-7457.

Cao, J., Sato, H., Takino, T. and Seiki, M. (1995). The C-terminal region of membrane type matrix metalloproteinase is a functional transmembrane domain required for pro-gelatinase A activation. J. Biol. Chem. 270, 801-805.

Chomczynski, P. and Sacchi, N. (1987). Single-step method of RNA isolation by acid guanidinium thiocyanate-phenol-chloroform extraction. Anal. Biochem. 162, 156-159.

Coleman-Krnacik, S. and Rosen, J. M. (1994). Differential temporal and spatial gene expression of fibroblast growth factor family members during mouse mammary gland development. Mol. Endocrinol. 8, 218-229.

Cordell, J. L., Falini, B., Erber, W. N., Ghosh, A. K., Abdulaziz, Z., MacDonald, S., Pulford, K. A. F, Stein, H. and Mason, D. Y. (1984). Immunoenzymatic labeling of monoclonal antibodies using immune complexes of alkaline phosphatase and monoclonal antialkaline phosphatase (APAAP complexes). J. Histochem. Cytochem. 32, 219-229.

Danø, K., Andreasen, P. A., Grøndahl-Hansen, J., Kristensen, P., Nielsen, L. S. and Skriver, L. (1985). Plasminogen activators, tissue degradation, and cancer. Adv. Cancer Res. 44, 139-266.

Danø, K., Behrendt, N., Brünner, N., Ellis, V., Ploug, M. and Pyke, C. (1994). The urokinase receptor. Protein structure and role in plasminogen activation and cancer invasion. Fibrinolysis 8, 189-203.

Desprez, P. Y., Roskelley, C., Campisi, J. and Bissell, M. J. (1993). Isolation of functional cell lines from a mouse mammary epithelial cell strain: the importance of basement membrane and cell-cell interaction. Mol. Cell. Differ. 1, 99-110.

Dickson, S. R. and Warburton, M. J. (1992). Enhanced synthesis of gelatinase and stromelysin by myoepithelial cells during involution of the rat mammary gland. J. Histochem. Cytochem. 40, 697-703.

Feiken, E., Rømer, J., Eriksen, J. and Lund, L. R. (1995). Neutrophils express tumor necrosis factor- $\alpha$ during mouse skin wound healing. J. Invest. Dermatol., 105, 120-123. 
Freeman, S. N., Rennie, P. S., Chao, J., Lund, L. R and Andreasen, P. A. (1990). Urokinaseand tissue- type plasminogen activators are suppressed by cortisol in the involuting prostate of castrated rats. Biochem. J. 269, 189-193.

Gack, S., Vallon, R., Schaper, J., Rüther, U. and Angel, P. (1994). Phenotypic alterations in fos- transgenic mice correlate with changes in Fos/Jun-dependent collagenase type I expression. Regulation of mouse metalloproteinases by carcinogens, tumor promoters, cAMP, and Fos oncoprotein. J. Biol. Chem. 269, 10363-10369.

Garbisa, S., Èrico, A-D., Grigioni, W. F., Biagnini, G., Caenzzo, C., Fastelli, G., StetlerStevenson, W. and Liotta, L. A. (1990). Type IV collagenase augmentation associated with colorectal and gastric cancer progression. In Genetic Mechanisms in Carcinogenesis and Tumor Progression (Ed. C. C. Harris and L. A. Liotta), pp. 203-212. New York:Wiley-Liss.

Gewert, D. R., Coulombe, B., Castelino, M., Skup, D. and Williams, B. R. G. (1987). Characterization and expression of a murine gene homologous to human EPA/TIMP: a virusinduced gene in the mouse. EMBO J. 6, 651-657.

Guenette, R. S., Corbeil, H. B., Léger, J., Wong, K., Mézl, V., Mooibroek, M. and Tenniswood, M. (1994). Induction of gene expression during involution of the lactating mammary gland of the rat. J. Mol. Endocrinol. 12, 47-60.

Gugliotta, P., Sappino, A., Macri, L., Skalli, O., Gabbiani, G. and Bussolati, G. (1988). Specific demonstration of myoepithelial cells by antialpha smooth muscle actin antibody. $J$. Histochem. Cytochem. 36, 659-663.

Hammani, K., Henriet, P. and Eeckhout, Y. (1992). Cloning and sequencing of a cDNA encoding mouse stromelysin 1. Gene 120, 321-322.

Helminen, H. J. and Ericsson, J. L. E. (1968). Studies on mammary gland involution. I. On the ultrastructure of the lactating mammary gland. J. Ultrastruct. Res. 25, 193-213.

Jhappan, C., Geiser, A. G., Kordon, E. C., Bagheri, D., Hennighausen, L., Roberts, A. B., Smith, G. H. and Merlino, G. (1993). Targeting expression of a transforming growth factor $\beta 1$ transgene to the pregnant mammary gland inhibits alveolar development and lactation. EMBO J. 12, 1835-1845.

Kristensen, P., Eriksen, J. and Danø, K. (1991a). Localization of urokinasetype plasminogen activator messenger RNA in the normal mouse by in situ hybridization. J. Histochem. Cytochem. 39, 341-349.

Kristensen, P., Eriksen, J., Blasi, F. and Danø, K. (1991b). Two alternatively spliced mouse urokinase receptor mRNAs with different histological localization in the gastrointestinal tract. $J$. Cell Biol. 115, 1763-1771.

Laiho, M. and Keski-Oja, J. (1989). Growth factors in the regulation of pericellular proteolysis: A review. Cancer Res. 49, 2533-2553.

Larsson, L.-I., Skriver, L., Nielsen, L. S., Grøndahl-Hansen, J., Kristensen, P. and Danø, K. (1984). Distribution of urokinase-type plasminogen activator immunoreactivity in the mouse. $J$. Cell. Biol. 98, 894-903.

Lascelles, A. K. and Lee, C. S. (1978). Involution of the mammary gland. In Lactation: A Comprehensive Treatise (ed. B. L. Larson and V. R. Smith), vol. 4, pp. 115-177. New York: Academic Press.

Lefebvre, O., Wolf, C., Limacher, J.-M., Hutin, P., Wendling, C., LeMeur, M., Basset, P. and Rio. M.-C. (1992). The breast cancer-associated stromelysin-3 gene is expressed during mouse mammary gland apoptosis. J. Cell Biol. 119, 997-1002. 
Li, F., Strange, R., Friis, R. R., Djonov, V., Altermatt, H.-J., Saurer, S., Niemann, H. and Andres, A.-C. (1994). Expression of stromelysin-1 and TIMP-1 in the involuting mammary gland and in early invasive tumors of the mouse. Int. J. Cancer 59, 560-568.

Maier, R., Schmid, P., Cox, D., Bilbe, G. and McMaster, G. K. (1991). Localization of transforming growth factor- $\beta 1,-\beta 2$. and $-\beta 3$ gene expression in bovine mammary gland. Mol. Cell. Endocrinol. 82, 191-198.

Marcotte, P. A., Kozan, I. M., Dorwin, S. A. and Ryan, J. M. (1992). The matrix metalloproteinase pump-1 catalyzes formation of low molecular weight (pro)urokinase in cultures of normal human kidney cells. J. Biol. Chem. 267, 13803-13806.

Marti, A., Jehn, B., Costello, E., Keon, N., Ke, G., Martin, F. and Jaggi, R. (1994). Protein kinase A and AP-1 (c-Fos/JunD) are induced during apoptosis of mouse mammary epithelial cells. Oncogene 9, 1213-1223.

Martinez-Hernandez, A., Fink, L. M. and Pierce, G. B. (1976). Removal of basement membrane in the involuting breast. Lab. Invest. 34, 455-462.

Matrisian, L. M. (1990). Metalloproteinases and their inhibitors in matrix remodeling. Trends Genet. 6, 121-125.

Mayberry, H. E. (1964). Macrophages in post-secretory mammary involution in mice. Anat. Rec. 149, 99-112.

Mignatti, P. and Rifkin, D. B. (1993). Biology and biochemistry of proteinases in tumor invasion. Physiol. Rev. 73, 161-195.

Okada, A., Bellocq, J.-P., Rouyer, N., Chenard, M.-P., Rio, M.-C., Chambon, P. and Basset, P. (1995). Membrane-type matrix metalloproteinase (MT-MMP) gene is expressed in stromal cells of human colon, breast, and head and neck carcinomas. Proc. Natl. Acad. Sci. USA 92, 2730-2734.

Ossowski, L., Biegel, D. and Reich, E. (1979). Mammary plasminogen activator: correlation with involution, hormonal modulation and comparison between normal and neoplastic tissue. Cell 16, 929-940.

Petersen, L. C., Lund, L. R., Nielsen, L. S., Danø, K. and Skriver, L. (1988). One-chain urokinase-type plasminogen activator from human sarcoma cells is a proenzyme with little or no intrinsic activity. J. Biol. Chem. 263, 11189-11195.

Ploug, M., Eriksen, J., Plesner, T., Hansen, N. E. and Danø, K. (1992). A soluble form of the glycolipid-anchored receptor for urokinase-type plasminogen activator is secreted from peripheral blood leukocytes from patients with paroxysmal nocturnal hemoglobinuria. Eur. J. Biochem. 208, 397-404.

Prendergast, G. C. and Cole, M. D. (1989). Posttranscriptional regulation of cellular gene expression by the c-myc oncogene. Mol. Cell. Biol. 9, 124-134.

Pyke, C., Ralfkioer, E., Tryggvason, K. and Danø, K. (1993). Messenger RNA for two type IV collagenases is located in stromal cells in human colon cancer. Am. J. Pathol. 142, 359-365. Pyke, C., Rømer, J., Kallunki, P., Lund, L. R., Ralfkioeer, E., Danø, K. and Tryggvason, K. (1994). The $\gamma 2$ chain of kalinin/laminin 5 is preferentially expressed in invading malignant cells in human cancers. Am. J. Pathol. 145, 782-791.

Rennie, P. S., Bowden, J.-F., Freeman, S. N., Bruchovsky, N., Cheng, H., Lubahn, D. B., Wilson, E. M., French, F. S. and Main, L. (1989). Cortisol alters gene expression during involution of the rat ventral prostate. Mol. Endocrinol. 3, 703-708. 
Reponen, P., Sahlberg, C., Huhtala, P., Hurskainen, T., Thesleff, I. and Tryggvason, K. (1992). Molecular cloning of murine 72-kDa type IV collagenase and its expression during mouse development. J. Biol. Chem. 267:7856-7862.

Reponen, P., Sahlberg, C., Munaut, C., Thesleff, I. and Tryggvason, K. (1994). High expression of 92-kD type IV collagenase (gelatinase B) in the osteoclast lineage during mouse development. J. Cell Biol. 124:1091-1102.

Robinson, S. D., Silberstein, G. B., Roberts, A. B., Flanders, K. C. and Daniel, C. W. (1991). Regulated expression and growth inhibitory effects of transforming growth factor- $\beta$ isoforms in mouse mammary gland development. Development 113, 867-878.

Rømer, J., Lund, L. R., Eriksen, J., Ralfkioer, E., Zeheb, R., Gelehrter, T. D., Danø, K. and Kristensen, P. (1991). Differential expression of urokinase-type plasminogen activator and its type-1 inhibitor during healing of mouse skin wounds. J. Invest. Dermatol. 97, 803-811.

Sakakura, T. (1991). New aspects of stroma-parenchyma relations in mammary gland differentiation. Int. Rev. Cytol. 125, 165-202.

Sato, H., Takino, T., Okada, Y., Cao, J., Shinagawa, A., Yamamoto, E. and Seiki, M. (1994). A matrix metalloproteinase expressed on the surface of invasive tumour cells. Nature 370, 61-65.

Stetler-Stevenson, W. G., Aznavoorian, S. and Liotta, L. A. (1993). Tumor cell interactions with the extracellular matrix during invasion and metastasis. Annu. Rev. Cell Biol. 9, 541-573.

Stoppelli, M. P., Corti, A., Soffientini, A., Cassani, G., Blasi, F. and Assoian, R. K. (1985). Differentiation-enhanced binding of the aminoterminal fragment of human urokinase plasminogen activator to a specific receptor on U937 monocytes. Proc. Natl. Acad. Sci. USA 82, 4939-4943.

Strange, R., Li, F., Saurer, S., Burkhardt, A. and Friis, R. R. (1992). Apoptotic cell death and tissue remodelling during mouse mammary gland involution. Development 115, 49-58.

Streuli, C. H. and Bissell, M. J. (1990). Expression of extracellular matrix components is regulated by substratum. J. Cell Biol. 110, 1405-1415.

Sympson, C. J., Talhouk, R. S., Alexander, C. M., Chin, J. R., Clift, S. M., Bissell, M. J. and Werb, Z. (1994). Targeted expression of stromelysin-1 in mammary gland provides evidence for a role of proteinases in branching morphogenesis and the requirement for an intact basement membrane for tissue-specific gene expression. J. Cell Biol. 125, 681-693.

Talhouk, R. S., Chin, J. R., Unemori, E. N., Werb, Z. and Bissell, M. J. (1991). Proteinases of the mammary gland: developmental regulation in vivo and vectorial secretion in culture. Development 112, 439-449.

Talhouk, R. S., Bissell, M. J. and Werb, Z. (1992). Coordinated expression of extracellular matrix-degrading proteinases and their inhibitors regulates mammary epithelial function during involution. J. Cell Biol. 118, 1271-1282.

Topper, Y. J and Freeman, C. S. (1980). Multiple hormone interactions in the developmental biology of the mammary gland. Physiol. Rev. 60, 1049-1106.

Vassalli, J.-D., Sappino, A.-P. and Belin, D. (1991). The plasminogen activator/plasmin system. J. Clin. Invest. 88, 1067-1072.

Walker, N. I., Bennett, R. E. and Kerr, J. F. R. (1989). Cell death by apoptosis during involution of the lactating breast in mice and rats. Am. J. Anat. 185, $19-32$.

Warburton, M. J., Mitchell, D., Ormerod, E. J. and Rudland, P. (1982). Distribution of myoepithelial cells and basement membrane proteins in the resting, pregnant, and involuting rat mammary gland. J. Histochem. Cytochem. 30, 667-676. 
Werb, Z., Mainardi, C. L., Vater, C. A. and Harris, E. D., Jr. (1977). Endogenous activation of latent collagenase by rheumatid synovial cells. Evidence for a role of plasminogen activator. N. Engl. J. Med. 296, 1017-1023.

Williams, W. L. (1942). Normal and experimental mammary involution in the mouse as related to the inception and cessation of lactation. Am. J. Anat. 71, 1-41.

Woessner, J. F. (1991). Matrix metalloproteinases and their inhibitors in connective tissue remodeling. FASEB J. 5, 2145-2154. 


\section{Figures}

\section{FIGURE 1}

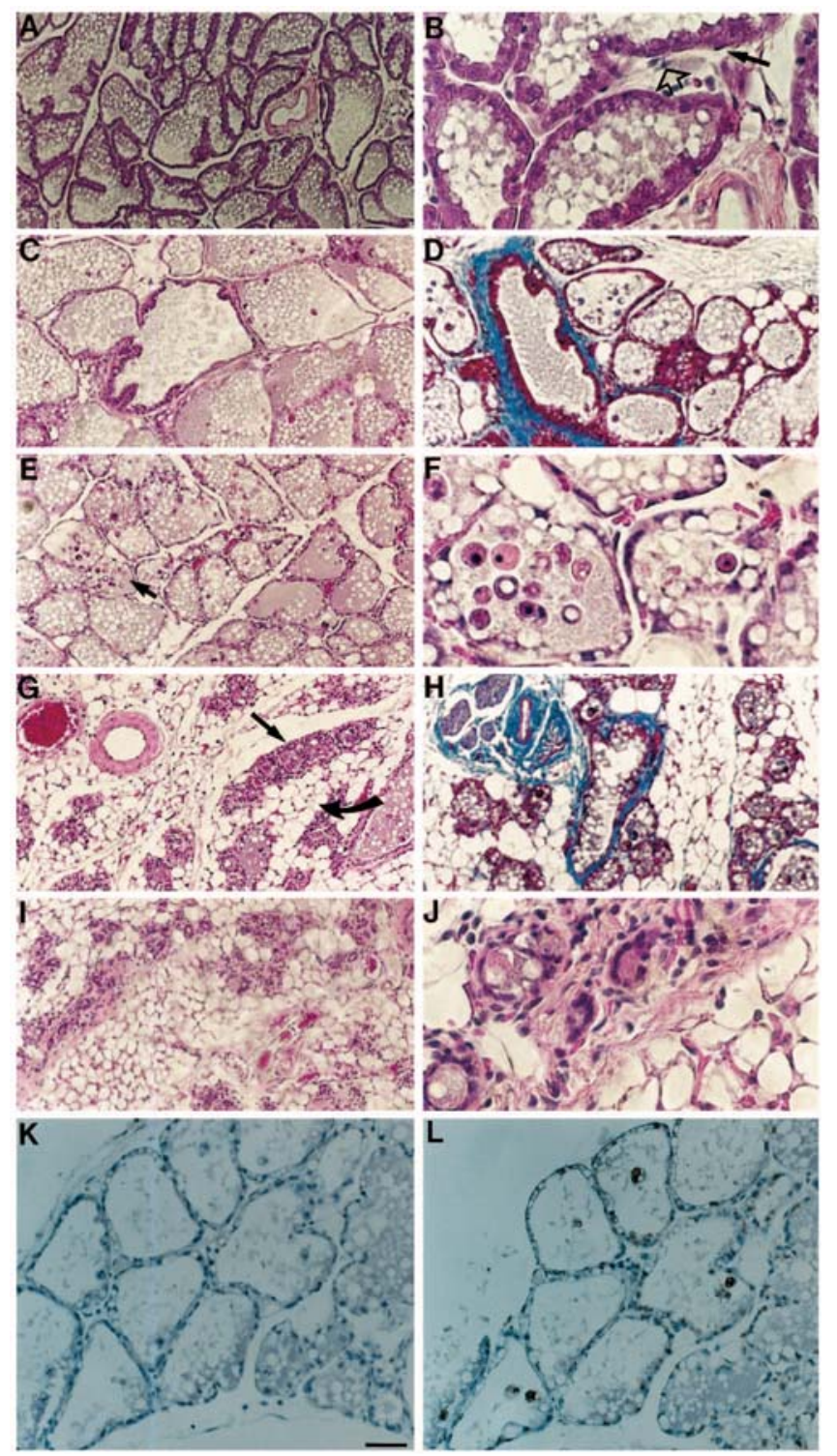

Hematoxylin-eosin and trichrome staining of lactating and involuting mouse mammary gland. (A,B) Mammary gland after 7 days of lactation. Open arrow indicates fibroblasts; solid arrow indicates myoepithelial cells. (C,D) Mammary gland after 2 days of involution. (E) Mammary gland after 3 days of involution. Arrow indicates apoptotic cells in the lumen of an alveolus shown in higher magnification in F. (G,H) Mammary gland after 4 days of involution. Straight arrow indicates a group of collapsed alveoli; curved arrow indicates adipocytes. (I,J) Mammary gland after 8 days of involution. (K,L) Staining for apoptotic cells after 3 days of involution. (K) control without and (L) with terminal deoxynucleotidyl transferase added. A,C,D,E,G,H,I, bar, $100 \mu \mathrm{m} ; \mathrm{B}, \mathrm{F}, \mathrm{J}, \mathrm{K}, \mathrm{L}$, bar, $25 \mu \mathrm{m}$. A,B,C,E,G,I,J were stained with hematoxylin and eosin; K,L were counterstained with hematoxylin; D,H were stained with trichrome. 


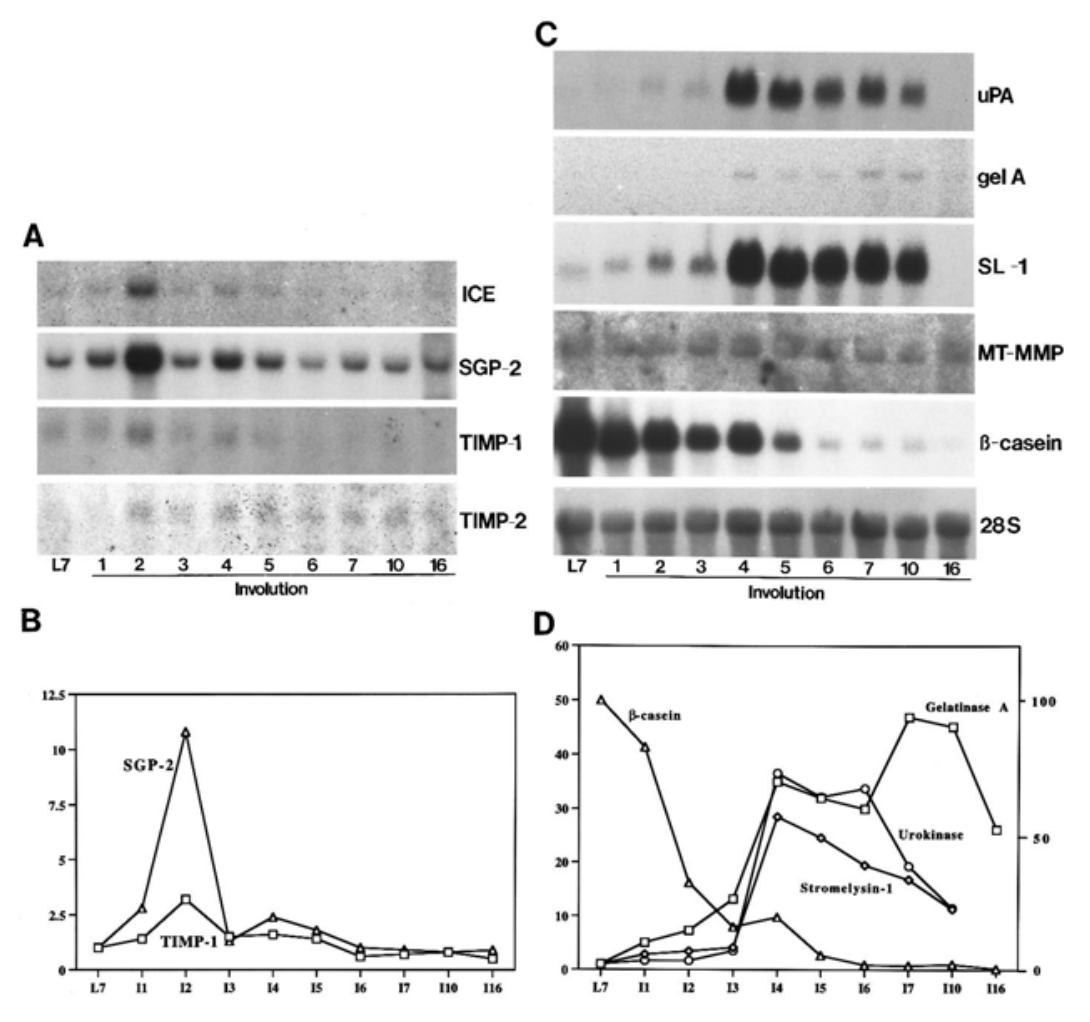

Analysis of mRNA isolated from mouse mammary gland involuting for various times. (A) RNA blot analysis for ICE, SGP-2, TIMP-1 and TIMP-2 in extracts of lactating or involuting mammary glands. The day within each stage is indicated below in arabic numerals. $20 \mu \mathrm{g}$ of total RNA was loaded in each lane. The blots were exposed for the following times: ICE, 8 days; SGP-2, 2 days; TIMP-1, 2 days; TIMP-2, 8 days. (B) Quantification of the mRNA signals obtained for the specific proteinase inhibitor TIMP-1 and the apoptosis marker SGP-2 in A. Probed blots were scanned in a PhosphorImager. The values obtained at day 7 lactation (L7), at the start of the involution, have been set equal to 1 , and the subsequent time points are indicated as -fold induction or reduction after normalization against the value obtained for the 28S RNA hybridization, in order to correct for the slight difference in loading and transfer of the various RNA samples. (C) RNA blot analysis for uPA, gelatinase A, stromelysin-1 (SL-1), MT-MMP, $\beta$ casein mRNA and 28S RNA. The blots were exposed for the following times: uPA, 3 days; gelatinase A, 2 days; stromelysin-1, 1 day; MT-MMP, 10 days; $\beta$-casein, 2 hours; 28S, 12 hours. (D) Quantification of the mRNA signals obtained for the proteinases and $\beta$-casein in C, as described above, except that the value obtained for $\beta$-casein at L7 was set to 100 . Numbers on the left indicate -fold induction of the proteinases, and on the right the reduction of $\beta$-casein expression. 


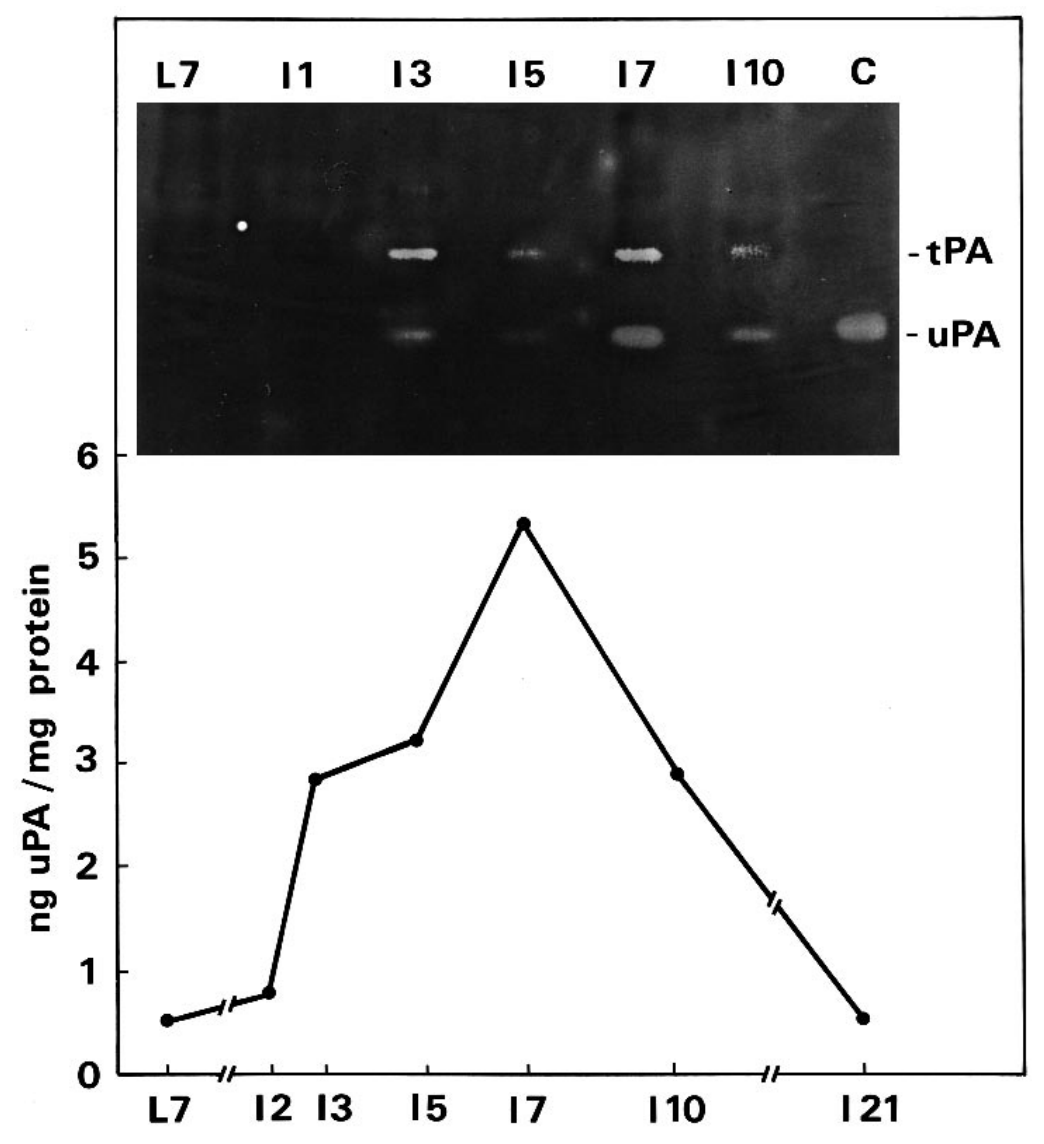

The uPA content of involuting mammary gland as determined by ELISA and fibrin zymography. Extracts were prepared from the inguinal and abdominal glands from mice that had been lactating for 7 days, followed by weaning for the indicated number of days. The concentration of uPA was determined by ELISA, and the protein concentration with the Folin-Ciocalteu reagent, as described in Materials and Methods. (Inset) Fibrin overlay zymography analysis of uPA and tPA activity in extracts of mammary glands. Tissue extracts (100 $\mu$ g protein) or $5 \mu$ l rat bladder urine were subjected to SDS-polyacrylamide gel electrophoresis and zymography as described in Materials and Methods. 
FIGURE 4
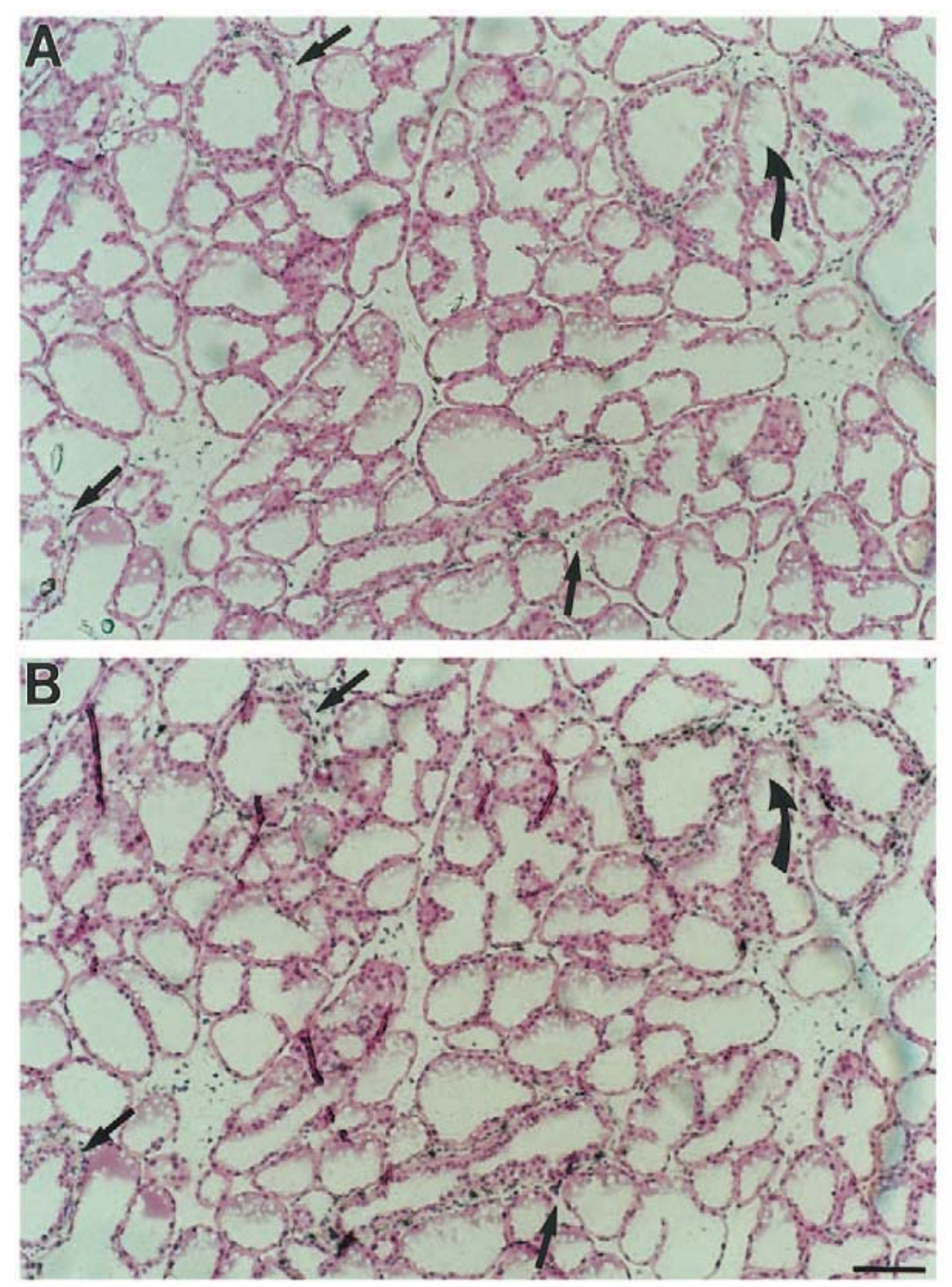

Distribution of gelatinase A and stromelysin-1 in 7-day lactating mouse mammary gland as detected by in situ hybridization. The sections were hybridized using antisense gelatinase $A$ RNA (A) or antisense stromelysin-1 RNA (B). Straight arrows in A and B indicate ducts positive for gelatinase A and stromelysin-1, respectively. Curved arrows indicate areas shown at higher magnification in Fig. 5A,C. Bar, $100 \mu \mathrm{m}$. 

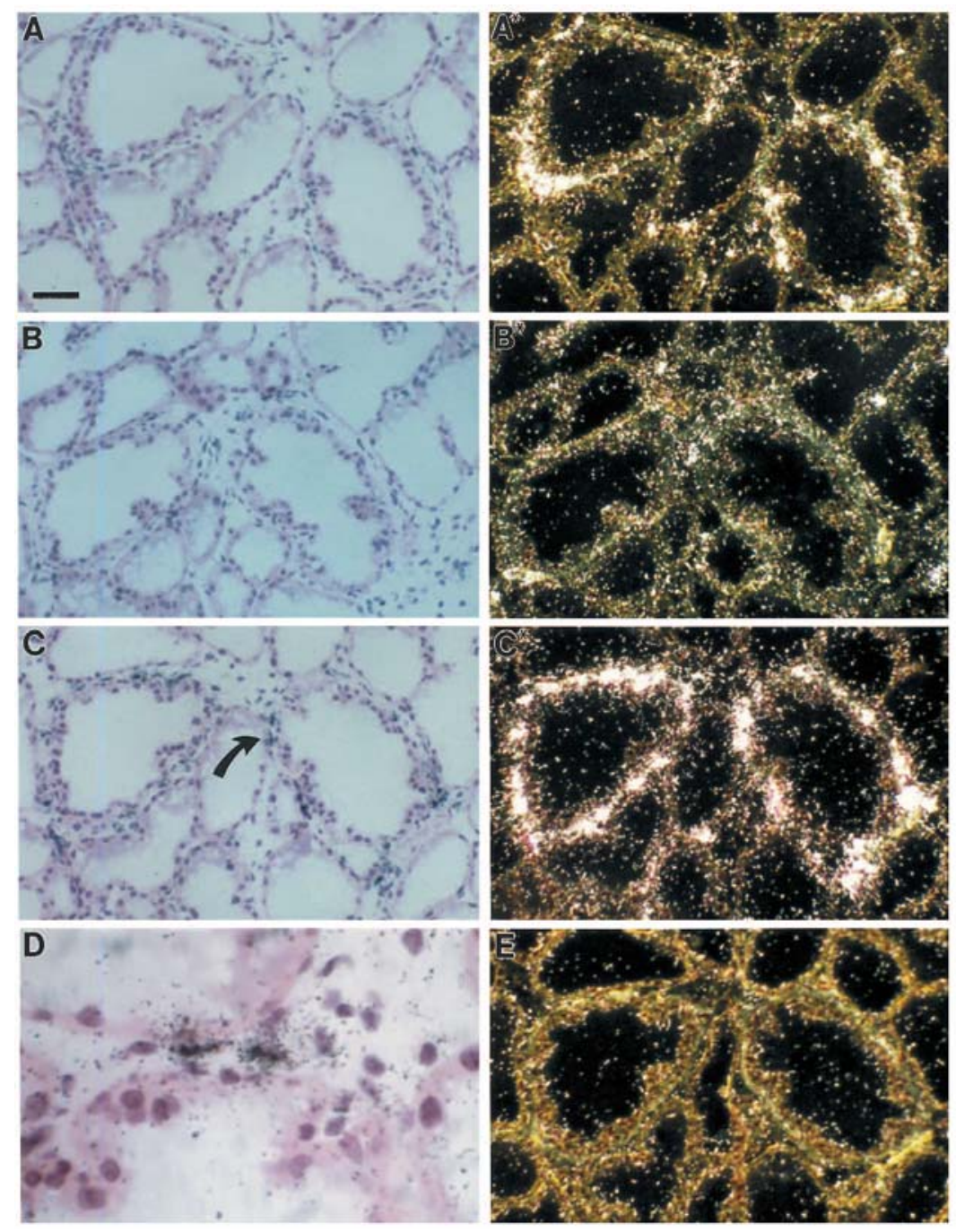

Distribution of gelatinase A, stromelysin-1 and uPA in 7-day lactating mouse mammary gland as detected by in situ hybridization. Higher magnification of the in situ hybridization shown in Fig. 4. The sections were hybridized by using antisense gelatinase A RNA (A,A*), antisense uPA $\left(B, B^{*}\right)$, antisense stromelysin-1 RNA (C, $\left.C^{*}\right)$, or sense stromelysin-1 RNA (E) as described in Materials and Methods. Tissue sections were viewed by bright-field (A-D) or dark-field $\left(A^{*}, B^{*}, C^{*}, E\right)$ microscopy. Arrow in $C$ indicates area shown at higher magnification in D. Positive control experiments were performed by application of two different antisense probes, covering nonoverlapping parts of each of the three cDNAs, as described in Materials and Methods. These probes were adjusted to the same specific activity and applied to adjacent sections of the mammary gland. In all cases, the two probes showed identical hybridization patterns for each specific mRNA (data not shown). As a negative control, sense RNA probes transcribed from each of the three cDNAs were applied to adjacent sections of all specimens, and in these sections no signal was obtained above background. In sections treated with RNase A before hybridization, no signal was detected with the antisense probes. $A, A^{*}, B, B^{*}, C, C^{*}, E$, bar, $25 \mu \mathrm{m}$; D, bar, $5 \mu \mathrm{m}$. 
FIGURE 6

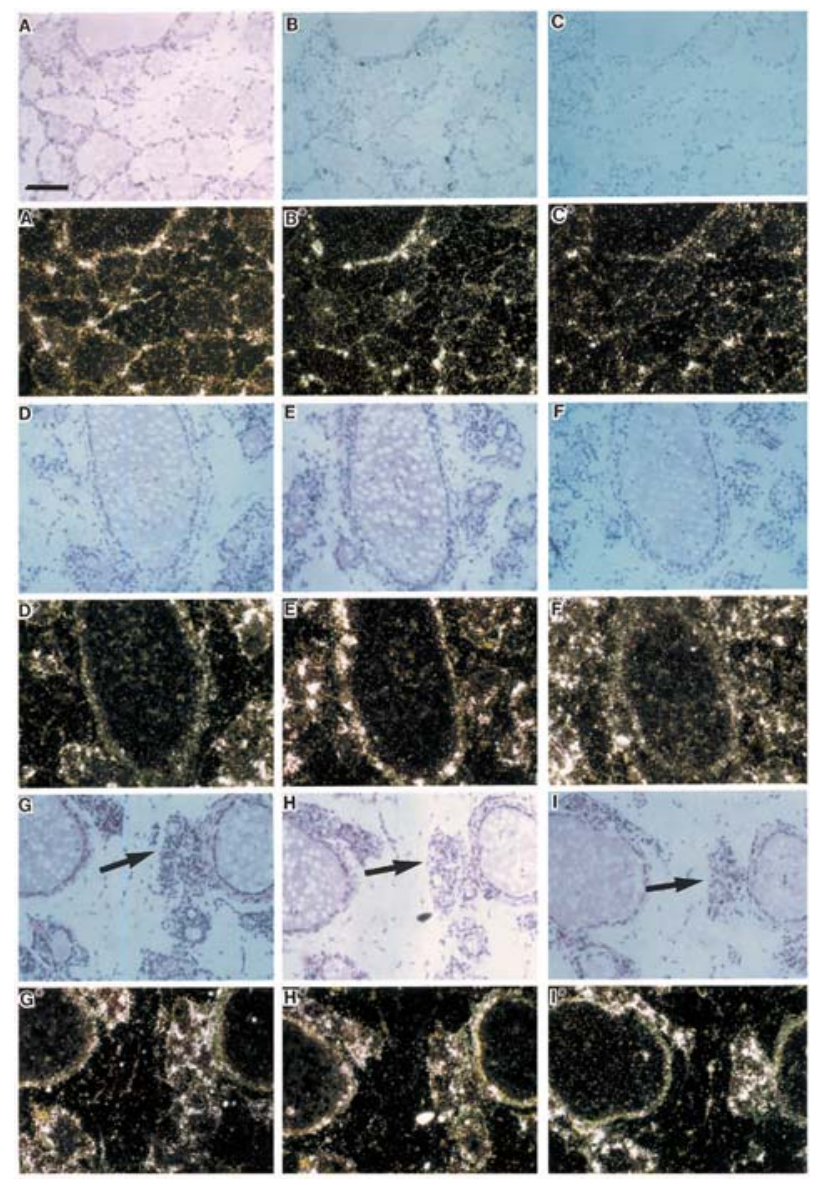

In situ hybridization for gelatinase A, stromelysin-1 and uPA mRNA in mouse mammary gland during involution. In situ hybridization analysis was performed on tissue isolated at day 3 (A-C, A*-C*), day 5 (D-F, D*-F*) or day 7 (G-I, G*-I*) after weaning. Photomicrographs of (A,D,G) gelatinase A expression; (B,E,H) stromelysin-1 expression; (C,F,I) uPA expression. Bar, 100 $\mu \mathrm{m}$. Arrows in G-I indicate areas shown at higher magnification in Fig. 7A-C. (A-I) Bright-field microscopy; (A*-I*) dark-field microscopy. 

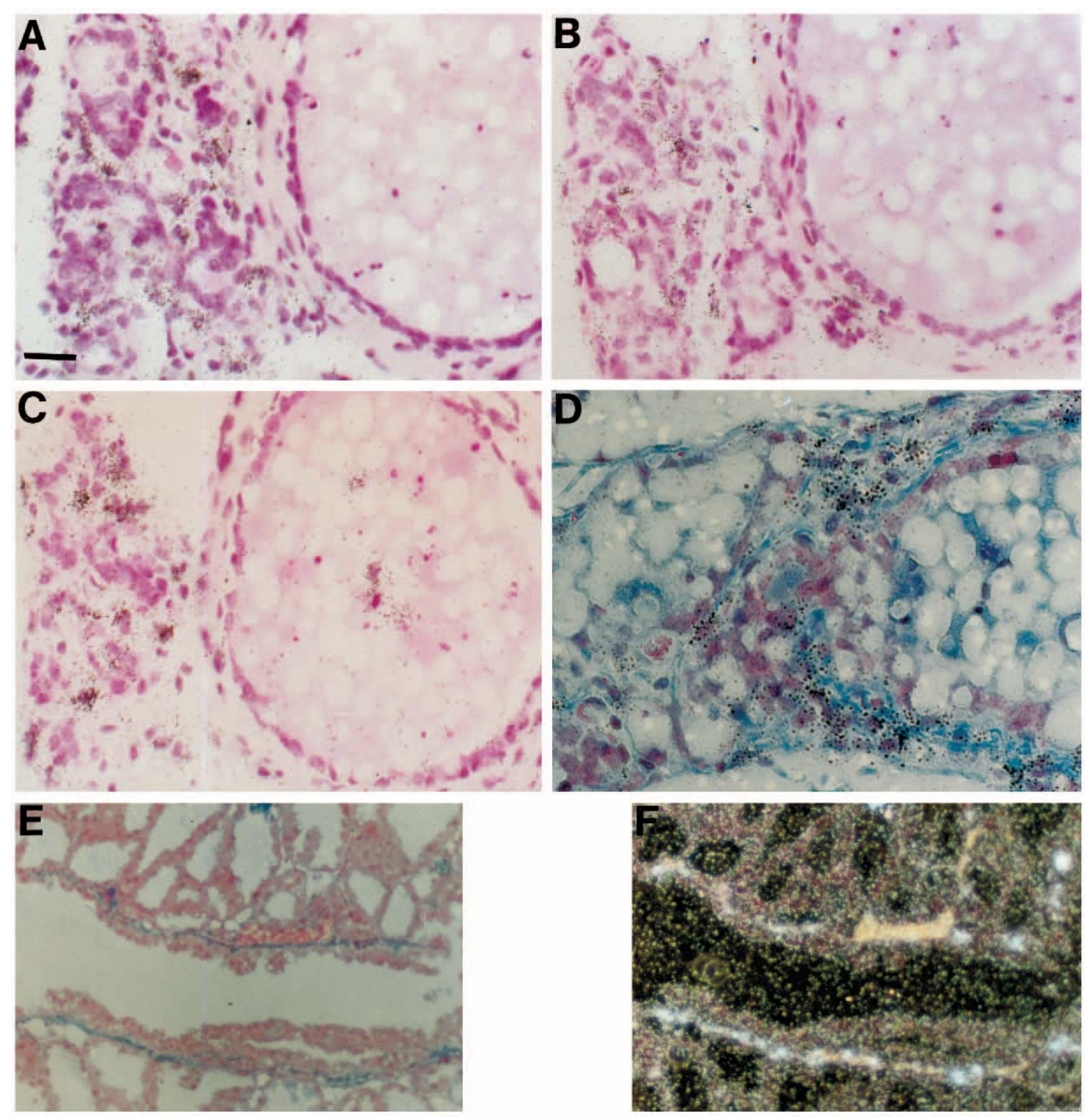

Localization of gelatinase A, stromelysin-1 and uPA mRNA in the mammary gland after 7 days of involution. A-C are higher magnifications of the in situ hybridizations shown in Fig. 6G-I for mRNA for gelatinase A (A), stromelysin-1 (B) and uPA (C). (D) In situ hybridizations for stromelysin-1 mRNA in transversal sections of day 7 involuting mammary gland, followed by trichrome staining. (E,F) In situ hybridizations for stromelysin-1 mRNA in longitudinal sections of day 7 lactating mammary gland, followed by trichrome staining in bright-field (E) or darkfield (F) microscopy. A-D, bar, $10 \mu \mathrm{m}$; E,F, bar, $25 \mu \mathrm{m}$. 


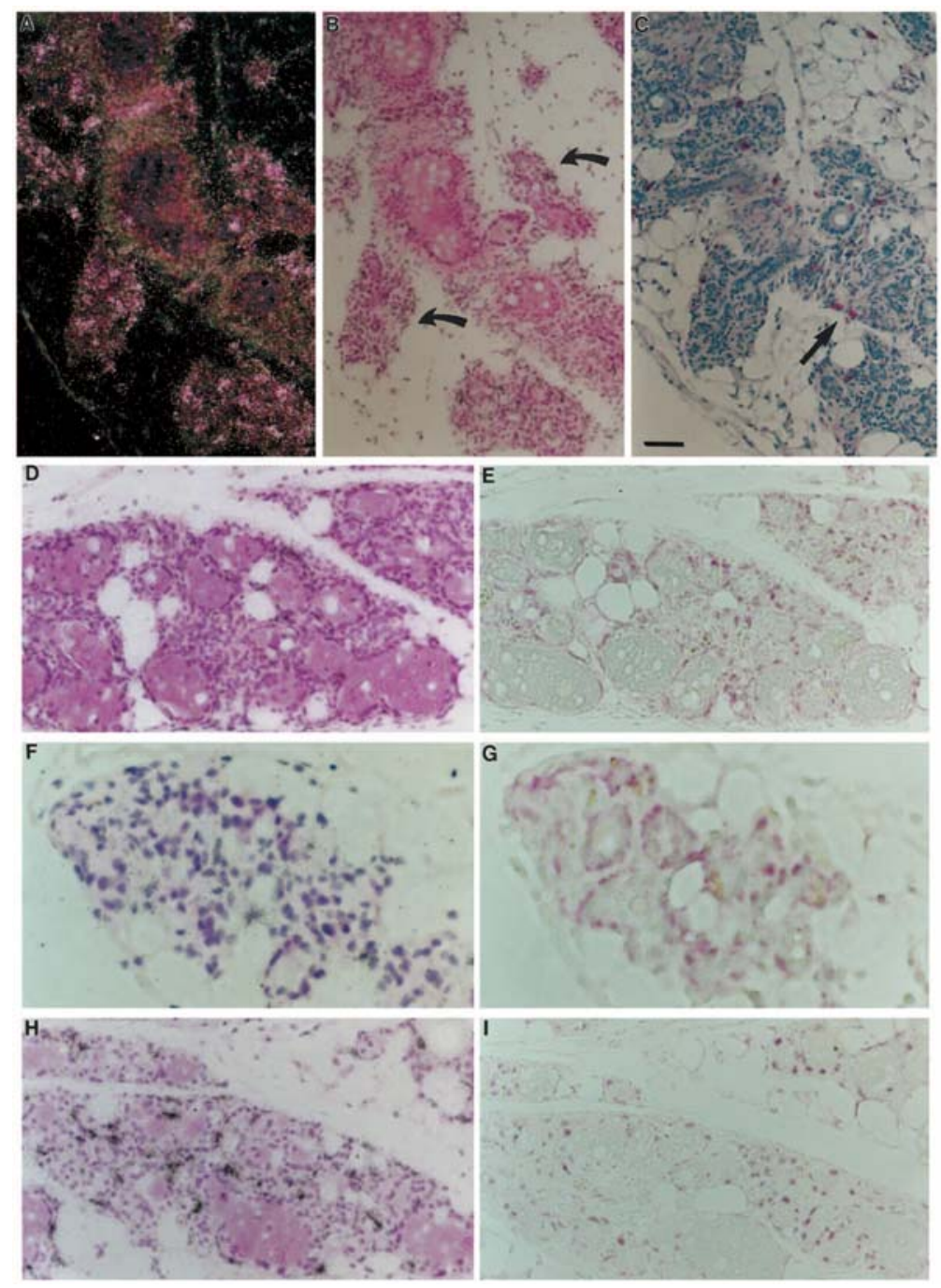

Immunohistochemical identification of cell types in involuting mammary gland.

Immunohistochemical staining for macrophagespecific antigens and smooth muscle $\alpha$-actin and in situ hybridization for uPA, stromelysin- 1 and gelatinase A were performed as described in Materials and Methods. (A-C) In situ hybridization for uPA mRNA and immunohistochemical staining for Mac-2 antigen on day 6 of involution. Adjacent serial sections of involuting mammary gland were hybridized with an antisense uPA RNA probe (A,B) or were stained with Mac-2 antibody (C). Curved arrows in A,B show areas positive for uPA mRNA, but with no macrophage-positive cells. Straight arrows in (C) point to macrophages present, but no uPA mRNA. (D-I) In situ hybridization for uPA, gelatinase A and stromelysin-1 and immunohistochemically staining for smooth muscle $\alpha$-actin antigen on day 6 of involution. Sections of involuting gland were hybridized with antisense RNA probes for uPA (D), gelatinase A (F) or stromelysin-1 (H), and adjacent sections were immunohistochemically stained for the presence of smooth muscle $\alpha$-actin (E,G,I). A-E,H,I, bar, $25 \mu \mathrm{m}$; F,G, bar, $10 \mu \mathrm{m}$. 

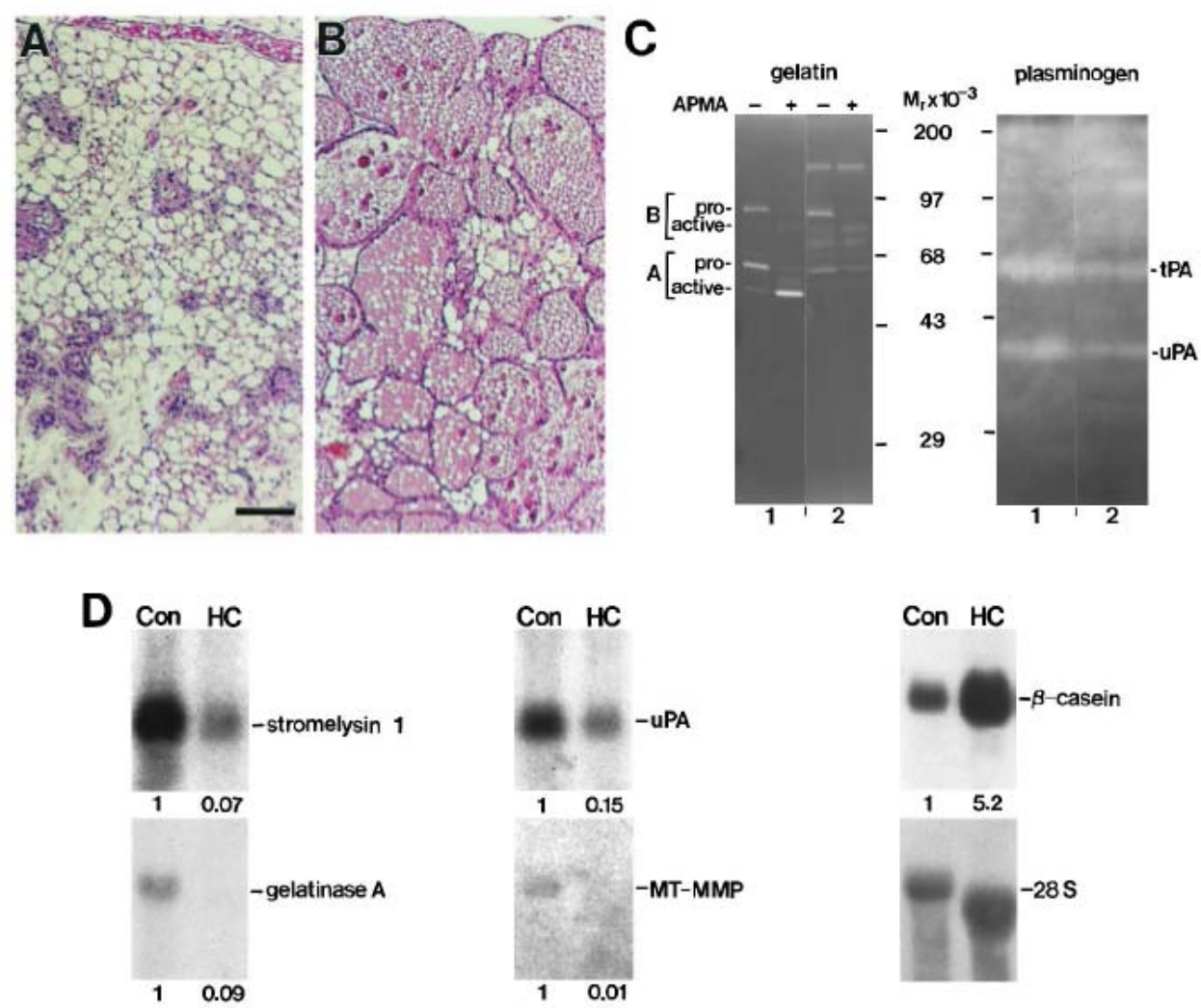

Effect of systemic treatment with hydrocortisone on the involution of the mammary gland. (A,B) Histological analysis of the mammary gland after involutioninhibitory treatment. Hematoxylin and eosin staining of mammary gland involuting for 5 days after daily subcutaneous injections of saline (A) or after daily subcutaneous injections of hydrocortisone (B). Bar, $100 \mu \mathrm{m}$. (C) Effect of hydrocortisone treatment on gelatinase and plasminogen activator activity. Substrate zymograms for gelatinases and plasminogen activators. (Lane 1) Involuting day 5, (lane 2) involuting day $5+$ hydrocortisone. + /- indicates in vitro 4-aminophenylmercuric acetate activation of the extract for 1 hour (+) or no activation (-). Samples from two different mice are shown for the plasminogen activator zymogram. The mobility of both uPA and tPA are slightly higher in substrate gels than in SDS-PAGE gels. (D) Effect of hydrocortisone treatment on specific gene expression. RNA blot analysis for gelatinase A, stromelysin-1, uPA, MT-MMP, $\beta$ casein and 28 S RNA. (Lane 1) Involuting day 5, (lane 2) involuting day 5 + hydrocortisone. After hybridization of the RNA blots with the various probes, the blots were analyzed in a PhosphorImager analyzer. After normalization to the level obtained for the 28S RNA, the value obtained at day 5 of involution without treatment was set equal to 1 for each probe, and the values after hydrocortisone treatment are indicated as -fold induction or reduction. The results shown are from a typical single experiment, which included pooled tissue extracts from at least 3 mice to reduce the effect of variability between individual mice. 